Portland State University

PDXScholar

2016

\title{
Mind the Gap: Gender's Effect on Quality of Elected Members of Parliament in the United Kingdom
}

\author{
Alyssa Lenore Herr \\ Portland State University
}

Follow this and additional works at: https://pdxscholar.library.pdx.edu/honorstheses

\section{Let us know how access to this document benefits you.}

\section{Recommended Citation}

Herr, Alyssa Lenore, "Mind the Gap: Gender's Effect on Quality of Elected Members of Parliament in the United Kingdom" (2016). University Honors Theses. Paper 227.

https://doi.org/10.15760/honors.225

This Thesis is brought to you for free and open access. It has been accepted for inclusion in University Honors Theses by an authorized administrator of PDXScholar. Please contact us if we can make this document more accessible: pdxscholar@pdx.edu. 
Mind the Gap:

Gender's Effect on the Quality of Elected Members of Parliament in the United Kingdom

\author{
Alyssa Lenore Herr \\ Political Science Honors and University College Honors \\ Undergraduate Thesis \\ Portland State University
}

February 2016 
The United Kingdom's ‘Bolton West' constituency has never been considered a stronghold for either of the U.K.'s most prominent parties. From 1997 to 2010, Bolton West's seat to the House of the Commons had been chaired by Ruth Kelly, a Labour Party Member of Parliament (MP). Ruth Kelly is an Oxford undergraduate and has a Master's degree from the London School of Economics. Before running for national election, she was active in her local Labour Party, an economics writer for 'The Guardian', and deputy head of the Inflation Report Division for the Bank of England. Prior to 1997, the Bolton West constituency had elected for three consecutive terms, Tom Sackville. A Conservative Party politician who also held an Oxford undergraduate degree. However, his qualifications for office, outside of the one previously mentioned, were sparse. In 1997, both candidates ran against each other. Ruth Kelly, nine months pregnant at the time, won the election with nearly a $50 \%$ majority.

In office Ruth Kelly served as the Secretary of State as well as the Minister for Women and Equality. Ruth Kelly stepped down before the 2010 general election and publicly put her support behind the Labour's new candidate for Bolton West, Julie Hilling. Hilling had lived in the constituency for twenty-five years and spent most of that time working for a trade union as its Senior Regional Organizer. She holds two undergraduate degrees and, prior to running for election, she was the president of the 'Community and Youth Workers' Union, a local Labour Party leader, and a North West Learning Organizer for the NASUWT (national trade union for teachers and women teachers). In 2010, Hilling ran against an equally qualified female Conservative Party candidate, but she marginally kept Bolton West for Labour. Then, in 2015, Julie Hilling ran against Conservative Party candidate Chris Green. Green was an engineer for twenty years in the Mass Spectrometry industry sector and had done work in Rwanda promoting 
engineer training. He had no previous ties to the constituency nor any prior political experience. Yet, in 2015, he marginally won Bolton West against the undeniably more qualified candidate, incumbent MP Julie Hilling.

How candidate gender correlated to candidate quality in Bolton West is not an uncommon phenomenon among the U.K.'s single member district (SMD) elections. Kelly is an incredibly overqualified candidate and Hilling is a very well qualified candidate. Sackville and Green, on the other hand, have less impressive resumes. Kelly's extensive experiences gave her an upper hand in electability. Yet, even when running against an arguably mediocre candidate, Hillings' above average candidate quality is unable to win the election. There seems to be something distinct about the female gender as a variable which alters election outcomes and makes it harder for women to win elections. Yet, without a detailed account of each candidate's political quality, the impression is that men and women are running as equals. Although, a closer look at just this one district's candidate history tells a very gendered story. The prevalence of using analysis methods for SMD races which are candidate quality indifferent has caused many to conclude that even though women and men don't run at equal rates, as there are fewer female candidates, at least women and men win at equal rates.

This conclusion, which mistakenly seems to be a common one, discounts the importance of valued experiences and political quality obtained prior to national election. It also ignores how gender may affect how much political quality a candidate seeks out prior to election. I argue that a historical exclusion from politics affects female candidates by making them overcompensate in political quality in order to overcome assumed negative gender biases held by political parties, political gatekeepers, voters and female candidates themselves. It is my belief that with closer 
examination it will become obvious that the sole variable of female gender increases political quality in SMD plurality electoral systems. If my theory is true, and men and women are winning at equal rates, but women are often the more qualified candidates, then it appears that women face more challenges to become a state representative than men. Their higher candidate quality is evidence of an gender biased political reality for women.

In order to explore the grounds for my proposed theory, this thesis will first address prevalent literature and research on the causes of women's underrepresentation in SMD. Different theories and scholars will be considered for possible, or supposedly non-existent, structural and cultural biases of female candidates. A review of past research will illustrate how male candidates often seem to have the upper hand on the path towards elected office, yet none of the literature will be able to specifically answer how this gendered path alters candidate quality. Therefore, in the next section, I will lay out my central theory of how I believe gender effects female MP quality and why.

The subsequent section will provide a detailed explanation of my testing methods. I will defend why I choose the quality test I created. I will also disclose why I choose the U.K.'s 2015 general election as my case study. In this section I will point out specific predictions for my research. The following results section will include a collective analysis of my data. My results section will also reveal that my findings support my original thesis. Finally, in my conclusion section I will confirm that the gender differences in candidate quality I observed are evidence of a deeply embedded and culturally reinforced gender bias in politics. This bias disguises as the modern democratic candidates emergence process in the U.K. 
Even in western democracies, such as the United Kingdom, where women have shared the right to stand for election for nearly a century, the parliament elected in 2015 is still seventy one percent male. Yet, my empirical research shows, that while female politicians at Westminster may be few and far between, they are anything but unqualified. If anything, these female politicians tend to be elected with more political experience than their male counterparts. If men and women really are viewed as, voted for, and recruited as equals, there should be a reason for these differences. However, there is a lack of academic consensus on whether gender influences perceived electability and consequently impacts candidate quality. Nevertheless, I will search for clues in past research as to why female gender may correlate to quality but not quantity.

Before considering how gender affects candidate quality and why, it is crucial to remember why gender balanced government is essential to democracy. A rather straightforward reason, brought up by Amy Handlin in "Whatever Happened to the Year of Woman?", is the importance of descriptional and symbolic representation. Both are achieved when members of a group in society see people who look like them in positions of power. Coincidentally, scholar Handlin speaks from experience. She served as a mayor, on university boards, and on the Board of Women Voters, before being elected as a Republican Congresswoman for New Jersey. She feels strongly that her own political visibility, and that of other female politicians, increases overall democratic legitimacy. Being an example of a vastly qualified female elected representative herself, she believes descriptional and symbolic representation has the ability to change political norms and break down gendered obstacles for female candidates. 
Scholar Wendy Stokes proves that not only do female representatives stand symbolically for women, they work for women. In "Women in Contemporary Politics" Stokes finds that female politicians tend to hold women benefiting legislation issues such as child care, education, women's reproductive health, women's rights, equal pay, and preventing domestic violence at a higher priority than male politicians (Strokes 22). Susan Carroll also highlights in "The Impact of Women in Public Office" how equal representation may be beneficial for overall government efficiency. Carroll's research finds female politicians to be better group facilitators, "more responsive than men to their constituents", and better at compromising (Carroll 19). Thus, if my research finds there is gender bias against female candidates, then democratic legitimacy, efficiency, and equal representation of half the voting population's priorities is subsequently impaired because of this bias.

Nevertheless, political scientists argue electoral systems create structural passageways that either help or hammer equal representation. For instance, Pippa Norris is one of many to point out how single-member districts won by the largest vote share, a plurality, like in the U.S. and U.K., are disadvantageous to female representation. With only one representative elected to each constituency, Norris believes female candidates suffer due to incentives for strategic voting. In "Electoral Engineering" Norris explains that strategic voting can hurt female candidates as it urges voters to vote for the candidate they like best, discounted by the probability they think the candidate has at winning. Likewise, in "Women and Legislative Representation", scholar Mason Tremblay coins the effect strategic voting has on candidate selection as a 'zero-sum game' for it's all or nothing characteristics (Tremblay 47). Norris and Tremblay are suggesting that if voters or political gatekeepers perceive unfavorable bias towards female candidates they will discount 
this bias against the perceived likelihood the candidate has at winning the most support. The affect strategic voting has on female candidates may be an overcompensation of personal quality to deter the lack of female quantity and perceived bias in SMD elections.

Multimember districts or proportional representation electoral systems, on the other hand, create incentives for both voters and political parties to "select a balanced ticket of women and men, younger and older, majority and minority ethnicity candidates" (Tremblay 47). Hence, scholars recognize that the very nature of Britain's majoritarian electoral system disenfranchises female representation. This is due to the fact that strategic voting creates electoral encouragement for political parties and voters to keep the status quo. The status quo of an elected official is overwhelmingly a man from the dominant ethnic group of the country. Consequently, SMD plurality completely sidesteps the democratic balancing act of other electoral systems as one candidate is held responsible for all the traits desired by voters and political parties. Since female candidates, or other non-caucasian males, are not the 'norm' candidate, they may overcompensate with other traits in absence of status quo appeal.

SMD incumbency further impedes female representation as incumbent politicians in single member districts have around ninety percent chance of reelection (Burrell 12). This is referred to as the incumbency theory and it is brought up by scholars Seltzer, Newman and Leighton in "Sex as a Political Variable". Their argument is that the lack of turnover in SMD electoral systems, not patriarchy and biases against female candidates, excludes more women from entering government. Or put rather boldly in their own words: "electoral success has nothing to do with sex, and everything to do with incumbency" (Seltzer, Newman and Leighton 7). These scholars are not alone in their conviction. Political scientist, Barbara Burrell, states in 
"Gender in Campaigns for the U.S. House of Representatives" that SMDs' electoral structure limits opportunities for newcomers, of either sex, to win seats. These scholars justify that with time and patience, women will gain seats and equal representation will be achieved. Since the United Kingdom lacks term limits for parliamentary seats, the likelihood that incumbency allows male career politicians to hold onto their seats is truthfully high. But if we can assume that some female candidates are not so patient, or perhaps some find the idea of waiting their turn undemocratic. Then, we can also see how that male dominated incumbency may affect female candidates by making them seek excess candidate quality in order to be successful in winning a 'barred off' seat. The incumbency and strategic voting theories are therefore useful in illustrating structural factors which informally discriminate against female politicians and might influence their quality levels.

Some scholars propose that through direct and intentional action, political parties have the ability to correct the adverse effects strategic voting and incumbency has on female candidates. Political parties remain the most influential recruiters and therefore have the ability to seek out female candidates and run them in winnable seats. Since the U.K.'s political system remains one of the strongest party systems in the world, where political parties assert much control over their representatives, this suggestion may be a valuable one. Yet, that hope may be a fleeting one because in "Where Women Run”, scholar Kira Sanbonmatsu proves that political parties hold their own biases against recruiting and running women.

Sanbonmatsu wanted to unpack a previous study which found: "when women run, women win", in equal rates to men (Sanbonmatsu 2). To discover if men and women really do run and win in exactly the same races, Sanbonmatsu conducted a thorough survey of political 
party leadership gender bias. Though this study was conducted in the U.S., I believe it is applicable to the U.K. as both nation's share similar electoral systems, political culture, histories of women's suffrage and have roughly two party systems (2.5 for the U.K.). Overall, Sanbonmatsu's research proves that political party leaders perceive it to be more difficult to run female candidates, especially in certain districts. Sanbonmatsu's data suggests political party leaders would be much more comfortable agreeing that 'where women can win, women run'.

Sanbonmatsu's survey research concludes that the perception of electability of female candidates by political party leaders is more geographically organized for female candidates than male. Specifically, Sanbonmatsu states: "the survey evidence contradicts the conventional wisdom that women's electability is no longer an issue: party leaders quite commonly believe that women's electability depends on the area" (Sanbonmatsu 116). For example, 54\% of state party leaders and $56 \%$ of state legislative leaders answered that there are 'yes, many' or 'yes, a few' districts in their respective states where it might be hard for a female candidate to win national election due to their gender alone (Sanbonmatsu 116). Therefore, party leaders work to "recruit and help nominate women candidates is likely to be influenced by these beliefs about voter behavior" (Sanbonmatsu 117).

If we consider that political party leaders put the highest priority on gaining or maintaining political power, then we can easily understand how political parties will recruit and nominate candidates through a gendered lens. If this is true, it means that women are held to an informal, but significantly higher, standard of candidate quality by political gatekeepers, who perceive their gender to negatively affect their chances of winning certain elections. It also 
means that while the so-called political arena is completely accessible for the average male candidate, certain districts are quicksand for the average female candidate.

To make matter worse, Sanbonmatsu found another gender specific difference when she surveyed current elected officials. She found that, while $55 \%$ of women politicians believe that 'men are sometimes more' or 'often more', encouraged by their party to become candidates, a slim 5\% of men agreed to the same question (Sanbonmatsu 125). The 'goold old boys network' is clearly harder to recognize from the inside out. If male politicians cannot recognize the extra hurdles female candidates must jump through to accomplish the same goals, and if political gatekeepers recruit through a discriminating lens, it is easy to see why female candidates may overcompensate with political quality to counteract these gendered obstacles to election.

Sanbonmatsu's findings are also important because they discredit the idea that because men and women are elected at similar rates, all races are the same. Her research proves that political party leaders are instrumental in recognizing that not all races are the same, and whether the voter bias they perceive is real or false, it plays into the recruitment and nomination of a candidate which is gender biased and geographically specific. Since the U.K. has a strong party system, evidence of women's electability bias by political party leadership would be apparent if women MPs displayed higher levels of candidate quality. This would be evidence of political parties picking only the most qualified female candidates, or the 'cream of the crop', to balance out the perceived consequences of their gender. Since Scotland has consistently elected more women to its regional parliament than any other nation in the U.K., confirmation of bias of women's electability by party leadership should be decreased in Scottish districts. 
Ironically, Sanbonmatsu found that states with the strongest party organizations tend to have less female candidates. Meanwhile states with weaker political party organizations had more female candidates. This is compelling because her findings go directly against the theory that stronger political party organization would create incentives for party elites to recruit higher numbers of female candidates. Instead, her data highlights how political parties make fewer formal or informal attempts to recruit female candidates, and furthermore, that political elites remain an exclusively male networking system. This male dominated networking system clearly still operates like the 'good old boys club' and denies opportunities to potential female candidates with increasing levels of party strength. These findings directly relate to my research in the U.K., since political party strength in the U.K. is so robust. Opportunities for candidates to run as independents, or to run in a district without careful political party consideration, are extremely low. Consequently, the U.K.'s party strength may create more incentives for female candidates to have higher levels of political quality in order for them to even be considered a viable candidate to the male dominated, and extremely influential, U.K. political parties.

On the contrary, scholar Kathleen Dolan disregards the role gender plays in electability and party recruitment. In her books "Voting for Women" and "When does Gender Matter?" Dolan theorizes that party identification trumps all in the minds of voters and remains the biggest predictor for voter choice. She argues that while gender and race may be the most 'pervasive' (first learned) traits voters will rely on, they are dwarfed in comparison to party id and incumbency. Unlike Norris, Dolan reasons that the effect gender stereotypes have on candidates is more pronounced in electoral systems with incentives for strategic voting. Her unpleasant, but perhaps valid, theory is that the negative biases voters hold against female politicians are masked 
by a priority to vote first and foremost for their preferred political party. A politician's personal characteristics, such as gender, should be completely overshadowed in SMD as parties only sponsor one candidate per district to maximize their vote share.

To prove this point, Dolan conducted a study, published in "Voting for Women", on how and when stereotypes affect female politicians in the U.S. House and Senate elections. Her study found the ability to handle 'stereotypical women's issues', such as childcare, education and women's rights, and 'stereotypical men's issues', such as defense and crime, based on a hypothetical candidate's gender was only 'periodically significant' (Dolan 133). Her conclusion was that, although the average voter does hold gendered views on the abilities of candidates, these stereotypes only become significant in certain electoral environments and should not be apparent in SMD elections. If Dolan's theory is true, gender would not correlate to greater MP quality because political parties would understand that party id would counteract any voter bias against female candidates. However, this argument seems weak, since SMD, by nature, are candidate based electoral systems. Therefore, a candidate's personal qualities tend to be exaggerated by their political parties, not masked, in SMD elections.

Nevertheless, Dolan claims her overall deduction is quite positive. She insists that people should 'spread the word' that "partisans embrace their party's women candidates" (Dolan 194). She imagines that knowledge of her study, which flips conventional wisdom of voter bias on its head, will turn the tables for female candidates running and being recruited. Yet, Sanbonmatsu's scholarly work would beg to differ. The gap between how Dolan's data coincides with Sanbonmatsu's findings and Norris's theory remains open. More importantly, how these differing factors: voter's commitment to party id, the good old boys recruiting network, a 
geographically gendered favorability constituency map, and strategic voting, influence MP quality is unknown.

But in "When Does Gender Matter?, Dolan addresses the possibility of variations in candidate quality. She states that despite women winning elections at equal rates to men, "some scholars have begun on the inconsistencies between these sets of findings, examining whether women candidates are at a higher quality than men, their winning at equal rates might signal some measure of bias in the political world, whether on the part of voters, the media, or other actors" (Dolan 144).

To give credit to the possibility of gender affecting candidate quality Dolan cites a 2013 study conducted by Kathryn Pearson and Eric McGhee. Pearson and McGhee's study found that female candidates for the U.S. House of Representatives had more experience in holding office prior to standing for election, compared to men (Dolan 145). There seems to be a possible contradiction between men and women winning at equal rates if women candidates are of a greater political quality than men. Are female candidates entering politics over-prepared based on a false perception of negative voter and political party bias? Or is negative voter and recruitment bias masked by this over-preparation?

In "When does Gender Matter?", Dolan raises some concerning facts on the inconsistencies. Her study concludes that publicly held stereotypes inform voters that women are better suited for local politics while male politicians are better suited for national politics. Perhaps, this would mean that we would find women entering national politics with more 'experience holding local office than men, such as in Pearson and McGhee's study. However, this would dramatically change the path for women entering national politics. It would be evidence 
of bias towards female candidates during national elections, since voters may find that out of two candidates with exact same qualifications, only the female candidate is less satisfactory without local office holding experience. This should not be brushed off lightly, because according to this favorability, even if men and women were elected at equal numbers, men would hold more influential political offices, while female candidates would have to prove more to reach the same posts.

Scholar Deborah Jordan Brooks likewise feels that the role of gender bias is over exaggerated in politics. Brooks is the former senior research director at the Gallup Organization. In her book,"He Runs, She Runs: Why Gender Stereotypes Do Not Harm Women Candidates", Brooks also addresses the possibility gender creating quality disparity. Brooks finds that "gender stereotypes are virtually nonexistent for candidates with a great deal of past political experience" (Brooks 13). This finding is instrumental to my own theory since it assumes that after a female candidate achieves absurdly high levels of candidate quality, she can be on a leveled playing field with average male candidate. In reality, how many female candidates are reaching this top-tier quality? It seems an unrealistic goal for equal representation if only a fraction of potential female candidates can endure this unbalanced challenge. However, if this is true, then female politicians would be more qualified than their male counterparts, in an effort to escape the damaging effects of gender stereotypes.

In Brooks' own study to investigate how gender affects voter behavior, she found that in regards to candidate experience, "men seem to benefit from experience more than women" (Brooks 76). For example, her study found that women who have held office for ten years compared with women who have never held office before, "there is simply no difference for 
experienced vs. inexperienced women" (Brooks 76). Oddly, Brooks concludes that the benefit men appear to gain from experience has more to do with inexperienced women's 'outsider bump' instead of "owing to some special kind of distaste for experienced women candidates" (Brooks 78) Therefore, Brooks argues that there is no 'double-bind' applied to female candidates.

But Brook's research seems to suggest that there is a different kind of double-bind. It appears that male candidates benefit from experience, while female candidates benefit from either extremely high levels of experience or no experience at all. However, strong cultural beliefs held by voters, female candidates, and political leaders sustain the idea that women are held to a higher standard and thus need to gain extra political experience. The newly defined double-bind is that female candidates may be working harder to receive no benefits from it. This would be obvious in my own research if women candidates achieved higher quality marks than men, but received less rewards, such as positions of power, for their experience. This is because studies of hypothetical female candidates usually find that voters still harbor at least some negative bias toward women candidates (Dolan 124). Therefore, it seems that women who win national election are perhaps better, in some way, than the men they run against. While Brooks' research may seem slightly contradictory, or perhaps even too optimistic, there is one very valuable point that can be taken away in regards to my own research. While some female politicians have managed to break that glass ceiling, women in generally have not.

To address the supply side problem Brooks brought up with women's representation, I turn to work done by Jennifer Lawless and Richard Fox. In "It Takes a Candidate: Why Women Don't Run for Office", Lawless and Fox conducted an expansive study on qualified potential 
candidates and found that women are much less likely to view themselves as qualified for political office. They asked roughly three thousand business leaders, top lawyers, university professors, successful activists and so forth, and concluded that women in exactly the same high quality professions as men, self evaluate their political abilities significantly lower. Even women with high levels of political participation and political interest display unfortunate low levels of political ambition. For example, of the qualified male candidates, only $12 \%$ perceived themselves as 'not at all qualified', meanwhile a whopping $28 \%$ of qualified females reported themselves 'not at all qualified' (Lawless and Fox 98). That's more than a quarter of the female eligibility pool self-disqualifying before the race even begins. To make matters worse, women are also much more likely to have negative perceptions of their abilities to win a race. For instance, Lawless and Fox found that while $31 \%$ of qualified women thought winning election would be 'very unlikely', only 19\% of men thought the same (Lawless and Fox 100). How this dramatic difference in perception affects candidate quality can only be assumed. Keen potential female candidates may neutralize this negative self perception by accomplishing goals they believe will increase their value and chances at winning election, such as serving in local offices and local party leadership. In other words, women may be deliberately increasing their political quality in order to calm subconscious gender specific insecurities.

This may be further exaggerated by the fact that Lawless and Fox found women are also less likely to receive encouragement to run for office from political party leaders, friends and family. Lawless and Fox found qualified females around $10 \%$ less likely to 'have ever received a suggestion to run for office' from a party official or elected official, and $8 \%$ less likely to receive a suggestion from a non-elected political activist compared to men in their same position 
(Lawless and Fox 101). However, they found exception to this lack of encouragement among women lawyers and activists. Therefore, if Lawless and Fox's findings applied to my own research, I may find that women with law and activist backgrounds are over-represented in parliament, relative to men with the same backgrounds.

Lawless and Fox believe women's negative self perception is culturally driven. They assert that qualified women lack political ambition due to what they call a 'lifelong gender socialization', which alters how women view their abilities and place in society. As a result of gendered socialization, women who are successful in other areas of their lives, such as education, finance and career, still can't fathom their success translating into political potential. Consequently, we find more women qualified for political office steering clear of politics relative to qualified men. Lawless and Fox's research therefore disproves the 'pipeline effect', the idea put forth by Brooks and others, that female representation is a supply-side problem. Because "despite starting out with relatively equal proportions of credentialed men and women, and regardless of the fact that women are just as likely as men to win elections, men are nearly twice as likely to hold elected office" (Lawless and Fox 47). They conclude that the devil is in the details when its comes to female candidates. "Socialized norms die hard" and the negative "notion of women serving in positions of high political power" may be one of the hardest to kill within the minds of voters, party leaders, and women themselves (Lawless and Fox 9).

After compiling their data, Lawless and Fox found that only $37 \%$ of qualified women would even ever consider running for office, compared with $64 \%$ of qualified men (Lawless and Fox 129). There is clearly a fork in the road to national office that is divided by gender. Lawless and Fox believe that due to the fact younger women did not express higher levels of political 
ambition, this gap in political ambition will endure as long as "deeply embedded traditions of gender socialization" continue to pervade society. Its cultural reinforcement will continue to make "politics a much less likely path for women than men" (Lawless and Fox 156). Traditional gender roles appear to discourage political gatekeepers, informal gatekeepers (friends, family, and partners), and individual gatekeepers (qualified women themselves) from recognizing women's political potential and valuing their political skillsets. Thus, while women continue to work hard to obtain degrees, be successful in their careers, and balance a disproportional amount of domestic responsibilities, the proportion of women seeking elected office will stay relatively plateaued unless there is a dramatic change in how women are taught to view themselves politically.

Similar research done by Katty Kay and Claire Shipman in "The Confidence Gap" illustrates how women's negative self-perception of their qualifications and abilities extends beyond the political arena. For example, Hewlett-Packard (HP), an international information and technology company, was trying to figure out how to get more women into top management positions. After reviewing personnel records, HP found that women applied for a promotion "only when they believed they met $100 \%$ of the qualifications listed for the job" (Altana 3). On the other hand, "men were happy to apply when they thought they could meet $60 \%$ of the job requirements" (Alanta 3). Correspondingly, in a study across business, scientific, educational, and other fields, Kay and Shipman found female confidence, and thus female ambition, to be significantly lower than men's. They conclude that "underqualified and underprepared men don't think twice about leaning in. Overqualified and over prepared, too many women still hold back. Women feel confident only when they are perfect. Or practically perfect" (Atlanta 5). 
The weight of traditional gender roles, double standards, and patriarchy, are still very much in existence in U.S. and U.K. society. These issues continue to weigh down highly accomplished women and prevent them from advancing forward, especially in one of the most historically male dominated spheres: national politics. Therefore, even though there is no formal system that excludes women from running or obtaining political office, there is a systematic, informal, and entrenched socialization process which makes women much less likely to seek national office. This results in fewer women recognizing their political potential, fewer women being encouraged to run for office, and, thus, fewer women willing to run for office. The impact of this gendered socialization on the few women who do pursue a political career is still curious.

How the conditions created by SMD electoral systems, party strength, gender bias recruitment, male-normative political culture, self-perceived qualification, strategic voting, and the importance of party id, influence women's candidate quality is not yet known. This literature review proposes some theories which suggest that female and male political quality should be more or less the same, while other scholars suggest that the differences in quality when correlated to gender should be quite robust. So while there are many theories which surround female underrepresentation, there is no one theory which connects female representation with political quality. My thesis research will therefore address gaps in the the literature regarding female political overachievement and underrepresentation.

\section{Central Theory Section:}

How we measure progress can be as important as how we define it. Unfortunately, in single member district electoral systems, the current system of measurement has restricted what it means to run as a female candidate. The impact of a candidate's gender is measured, more 
often than not, in absolutes and gender progress is calculated in zero-sum scores. For example, the 2015 British Parliamentary election were declared a great advancement of women in British politics due to the historic number of women elected. Now I am not disputing the fact that numbers do, of course, count. What I am disputing is how politics relies too heavily on numbers alone to tell the story of gender equality. The path to equal representation appears too frequently to be riddled with mathematical diction. For example, in 2015 it was boasted that Westminster gained forty-five new female Members of Parliament. Another report stated 'one in every three' British MPs is now a woman, as opposed to 'one in every five' in 2012. Better yet, it was announced that women currently make up $29 \%$ of the U.K.'s legislative body.

First, in this current political environment it becomes obvious that an MP's gender is counted in a quality indifferent manner. The low numbers of female representatives should be a signal to gendered challenges, but more importantly, these numbers say nothing about the candidates' quality. Therefore, my thesis reexamines the statement: 'when women run, women win' at equal rates to men. If women are winning at equal rates to men, but there is evidence of voter bias, recruiter bias, party leadership bias, and negative bias women hold of themselves, then the women who are winning elections must have some advantageous trait. I believe that this trait is a recognizable gathering of candidate quality prior to national election. Certain women are gaining quality leverage to counterbalance bias and political gatekeepers are looking for those higher qualities in female candidates.

My theory is then that candidate quality significantly increases when gender becomes a factor. This increase is due to the normalization of holding female candidates to a different, and arguably higher, standard, due to a history of exclusion from politics. This historical exclusion 
has created a male normative and male dominated political culture which incentivizes women to meet greater levels of candidate quality prior to national election. This absolutely changes what it means to be a female candidate and the political realities of female politicians. If supported, my theory confirms that sexism plays a prevalent role in modern democracies, and this role is exaggerated by single member district plurality electoral systems. With only one candidate from each party to choose from, voters, political parties, and female candidates themselves, undervalue women candidates and hold them to a higher ideal. This narrows the pool of female candidates and the eventual number of female politicians. It also leaves the remaining elected female representatives with higher levels of political quality than their male counterparts.

I speculate this is due to the gendered life-long socialization process, introduced by Lawless and Fox, which is more restrictive and demanding of women. Since women are taught to undervalue their abilities, I anticipate women are only comfortable becoming a national candidate if they acquire more qualifications than an average male candidate. Otherwise, average qualified women are likely found ineligible by voters, recruiters and themselves, due to the strategic voting tactics reinforced by the small, but damaging, bias Sanbonmatsu and Brooks prove political gatekeepers and voters still harbor concerning women's electability. Elected women are therefore more likely to be seasoned politicians who have extensive résumés of past experience than elected men. Gaining more experience before running for election allows these women to counteract non-institutionalized, yet systematic, political sexism. In this way, the negative consequences of running as a female candidate can be overlooked, or at least decreased.

These elected women could be so overqualified for office that they mask the informal discrimination the average qualified female candidates face. Therefore women candidates who 
are able to overcompensate their gendered disadvantages with quality, and win election, should not be taken as evidence of women winning the system. They are simply fooling it. If a female candidate must work harder than a male candidate to be elected, then the democratic system is clearly flawed, not to mention, undemocratic. Furthermore, it is undeniably unfair to half of the voting population's gender to be held to higher standards of quality. The fact that these differing quality standards are not institutionalized and are reinforced by cultural and political norms, rather than law, should not make them excusable. Alternatively, it can make their corruption to political equality more fortified as the debate around equal representation remains concerned with numbers and percentages. Instead, it could focus on the removal of gendered obstacles female candidates face in order to achieve the same goals as male politicians.

Without recognition that single member district plurality, in particular, is silently discriminating against a candidate's gender, the U.K. loses validity as a democratic institution. Along the same lines, without the recognition of how historical political exclusion creates divergent gendered quality acceptability, female candidates will always be disadvantaged and one step behind their male counterparts. I argue that this gendered difference is notoriously detrimental to the advancement of women's political equality and representation. But more importantly, it hampers the legitimacy of the electoral process of the U.K. and other SMD electoral systems. Democratic legitimacy is jeopardized because this process targets and disadvantages female candidates and disables equality and fair representation promised by law to all citizens of the United Kingdom. But by changing the way we measure progress and looking at quality instead of quantity, I believe the gendered restraints on female politicians can be proactively loosened. 


\section{Methodology}

In order to see if gender really does correlate to higher levels of political equality in elected representatives under SMDs, I needed to find an admirable case study. I chose to do my research using the United Kingdom's 2015 general election for several such reasons. First, since I believe the effects gender has on MP quality would be exaggerated in SMD, the U.K. makes for a prime example of a long standing democracy with a SMD plurality electoral system. Secondly, the longevity of women's suffrage in the U.K. should rule out the possibility of my data being swayed by recent sex integration of politics. The U.K. is also home to one of the strongest party systems in the world, and this system is nicely entrenched in a roughly two party system of moderate right and left political ideology. Other contending parties are either minor regional parties or the Liberal Democratic Party, a modest libertarian party. Additionally, the acclaimed 'pragmatic' political culture which orchestrates British political parties and politics should curb the possibility of a spurious relations between gender and MP quality.

Hence, the U.K.'s political party system is an arguably moderate and predictable one. This is important for my research as voters and parties in a long standing democracy, in theory, should not hold negative biases against female candidates. Additionally, the U.K. should be accustomed to female politicians and women in positions of high political power since Prime Minister Margaret Thatcher led the country for nearly two decades. Collectively, the very nature of the U.K.'s enduring political system and political culture creates a controlled environment where the effects of gender on MP quality can be easily isolated variables.

The U.K. general election cycle of 2015 was also secure from surprises, though admittedly, there were some. It was predicted to be a close call between the two main political 
parties: the Labour Party and the Conservative Party. Yet, the Conservative Party surprised almost everyone, most notably perhaps themselves, by winning the general election. The Conservative Party's $37 \%$ plurality win translated into roughly $51 \%$ of the vote share in the House of Commons. Normally, since the U.K.'s Conservative Party is known for having a bit of a 'lady problem', meaning that they have significantly less female candidates and MPs than their rival, the Labour party, their unexpected win could have been detrimental to my data collection. However, the Scottish National Party, led by its extremely popular and highly respected female party leader, Nicola Sturgeon, made up for the loss of female MPs. The SNP gained an unexpected fifty seats, with twenty of these seats being chaired by women. This made the 2015 U.K. election cycle a robust pool to study as it was the most female MPs ever elected to Westminster. Consequently, the U.K.'s 2015 election cycle was a formidable, if not exceptional, case study for research on how gender affects political quality under SMD.

In order to discover how and when gender affects political quality in SDM democracies, I created a quality test and tested it on every single one of the six hundred and fifty MPs elected in the 2015 election cycle. I recorded general information such as the MP's sex, party id, incumbency and minority status, due to race, sexuality or religion. I added nine qualifications I thought would be the most prudent traits candidates could use to enhance their political quality. These included four categories pertaining to higher education levels such as obtaining a master's degree, $\mathrm{PhD}$, or law degree and or attending a prestigious university, including undergraduate. I counted prestigious universities to be any of the U.K.'s top ranked fifteen universities from a list provided on the "Study in the U.K." government website. I also counted attending Ivy League universities in the U.S. for the this category. 
The remaining five quality categories took into account jobs or experiences that I thought would directly contribute to raising the quality of a candidate. These were comprised of holding local elected office prior to national election. Such as serving as mayor, on a school board, as a Trade Union officer, in a regional parliament, or in the Greater London Authority, previously known as the London City Council. The other four categories I considered included holding a local, regional or national political party leadership position, having worked as a lawyer, barrister or judge, working for an elected MP, or being an accomplished activist. I considered an activist accomplished if they had received any type of award or recognition for their work, if they had created a charity for their cause, or if they had written extensively on the subject.

I also added five 'awards' categories to test how gender affects promotions once in Westminster. For rewards, I recorded positions of power and documented if the MP had ever been a Party Leader, a Cabinet Leader, a Shadow Cabinet Leader, a Whip, or be given the title 'the Right Honorable' from the British monarch. Once this quality test was assembled, I went through all of the MPs elected in the 2015 election and individually researched how many quality marks and awards marks each MP earned. Fortunately, since the British election had only been a few months before my research, much of this information was easily accessible. For instance, I found the vast majority of the information on government issued websites or official political party websites. The rest of the information I collected from local newspaper articles, flyers, and individual MP informational websites.

If the data I collected supports my theory, then I would expect to find elected female MPs to have higher average quality scores, in a wide range of categories, compared to the average male MP quality scores. Specifically, I would expect women MPs to have more experience 
holding local office, prior to national office, than men. This would support Brooks' data which claims that gender stereotypes held by voters make female politicians more favorable to local politics. Support for this is reinforced by Shipman and Kay's research which claims that women only apply for a job after they meet all, or almost all, of the qualifications needed for the job. Previous local office holding experience most easily translates to national office qualification. Furthermore, due to Lawless and Fox's survey research on encouragement, if I discover that significantly more female MPs come from activist and law backgrounds, then my research would support Lawless and Fox's research on gendered socialization.

If my research supports Sanbonmatsu's findings on party recruitment and party leadership bias based on where women can win elections, then I would expect to see the geographic organization of women in elected office. For instance, if Sanbonmatsu's findings run parallel to my own, I would expect to see more women elected in Scottish districts. Since the Scottish parliament has continually elected higher levels of female representatives. Women's electability in Scotland would confirm how voter bias, political party recruitment bias, and women's negative self-perception decrease as the normalization of women in office removes gendered obstacles from the path of women attempting to attain office.

Provided that my data shows the average woman's quality to be significantly higher than that of the average man's, it would be evidence that women overcompensate quality in order to overcome rightfully perceived bias against female candidates. In other words, female MPs need to gain more experiences prior to elections than male MPs due to an informal candidate shaping and selection process that is more discriminating for women than for men. However, if my data showed that elected female and male MPs had relatively the same quality scores, and women 
were not elected in geographic groupings, then it would mean that men and women share the same paths to elected office and face the same odds and obstacles. So if gender as a variable makes no difference for the quality of a candidate, then my theory is not supported by my data.

\section{Discussion of Cross Tabs Data Results}

Overall my data showed that my theory was supported. From my research pool I found the one hundred and ninety one female MPs met more qualifications than the four hundred and sixteen male MPs. My data revealed that, across all party lines and controlling for incumbency, sex remained a key predictor for increased levels of political quality. Women MPs consistently had higher average scores on the vast majority of categories of political quality. For instance, data contained in Tables 5 and 6 show that prior to being elected to parliament, female MPs were a whopping $10 \%$ more likely to be elected to local government positions and $6 \%$ more likely to hold local or national political party leadership positions compared to male MPs. Likewise, while $26 \%$ of female MPs worked for an elected member of parliament prior to their own election, only $21 \%$ of male MPs had done the same (see Figure 8). Notably, Table 9 showcases that the most substantial difference in quality I found between female and male MPs was in the accomplished activists category. A whopping 56\% of female MPs were recognized activists for a particular issue. Meanwhile, only a quarter of their male counterparts scored the same.

The least difference in quality score averages between male and female MPs was regarding their educational qualifications. Tables 1 and 4 reveal that there was no significant difference between male and female MPs in regards to obtaining $\mathrm{PhDs}$ and attending prestigious universities. Nevertheless, Table 3 shows that while only one out of every five male MPs 
possessed a Master's Degree, one in every four women had obtained one. Women MPs also scored $3 \%$ higher on average in having a law degree compared to men MPs (see Figures 2).

Sadly, while my data illustrated that female MPs consistently scored higher in nearly all areas I tested for political quality, my data also found female MPs to be rewarded less with positions of power once inside Westminster. For instance, Table 11 highlights how $20 \%$ of male MPs were made Cabinet Leaders while only $16 \%$ of female MPs were given the same position. Similarly, Table 14 illustrates how only $10 \%$ of female MPs were given the 'Right Honorable' title (part of the Queen's privy), compared to $15 \%$ of male MPs. Male MPs were also 3\% more likely to be made whips than female MPs (see Figure 12). However, I found no real difference between the appointment of men and women to Party Leader and Shadow Cabinet Leader positions. Though this could have more to do with Labour and SNP being out of government. Nevertheless, my data demonstrates that women MPs who scored higher quality scores, received less influential and powerful positions in Westminster relative to male MPs with lower quality scores. It appears that the fruits of female labor and experience are devalued while men's are overvalued. However, Table 15 displays that, while Scottish National Party female MPs scored high quality averages, similar to the rest of the female MPs surveyed, they were rewarded differently. I found there to be an equal number of male and female Shadow Cabinet Leaders for the SNP.

Perhaps the best evidence I found to support how female gender increases political quality, but lowers the chances an MP has of gaining positions of power, was revealed when adding the minority status variable. First off, minority MPs of both sexes scored significantly higher in the majority of categories I tested for political quality. Compared to non-minority, 
especially non-minority male MPs, minority MPs consistently outranked their non-minority counterparts in quality. Minority MPs were also far more likely to come from a law background than non-minority MPs. Table 2 highlights how $38 \%$ of female and $30 \%$ of male minority MPs held law degrees, while only $16 \%$ of female and $14 \%$ of male non-minority MPs held the same. Lawless and Fox's findings in encouragement seem to be exaggerated for minority MPs. In particular, minority women had the highest quality scores in almost every category I tested, out ranking minority males, non-minority females, and non-minority males. Collectively, I found female minority.MPs to be the most qualified MPs at Westminster in 2015. Yet, despite minority women having the highest quality averages, male minority MPs were more likely to be rewarded with positions of power.

Table 11 shows how minority male MPs were $17 \%$ more likely than minority female MPs and 16\% more likely than non-minority female MPs to be made a Cabinet Leader. Additionally, there is a drastic difference noted between men being given the 'Right Honorable' title, when compared to females. For example, minority males are $11 \%$ more likely than minority females and $8 \%$ more likely than non-minority females to be appointed to the Queen's privy. Likewise, Table 13 illustrates how 39\% of male minority MPs were made Shadow Cabinet Leaders, compared to $35 \%$ of minority female MPs. These averages are higher than non-minority women and men MPs who became Shadow Cabinet Leaders. However, since minority women are the highest quality MPs overall, but male minority MPs are rewarded more for their efforts, there appears to be a gender biased rewards system within Westminster.

The fact remains that across the board, and across party lines, female MPs fulfill more qualifications than their male counterparts and are rewarded less with positions of power, despite 
their higher political qualifications. Meanwhile, both minority male and female MPs meet even more qualifications than their non-minority counterparts, yet only the men seem to benefit from their higher scores. Therefore, female minority MPs are the most qualified politicians, based on my research, and they are also the least likely to benefit from their superior preparations and past experiences. Consequently, gender appears to limit the rewards that can be reaped from experience for female MPs while it does not have the same effect on male MPs.

\section{Conclusion}

The basis of my theory rested on the belief that sex remains an undeniably important predictor for candidate quality. My empirical research showed female gender does in fact translate to higher candidate quality. This means that female MPs elected in the U.K.'s 2015 general election, on average, and in almost every category, exceeded more qualifications for office than their male counterparts. The partnership between higher MP quality scores and gender highlights the relationship between gender and political success.

Men and women do not share the same path to political office. A woman's path to national office in the U.K. is arguably more burdensome than a man's path. Furthermore, once in office, women receive less, despite differences in labor. Political agents, qualified women, political leaders, and voters all help shape this gendered path based on a perception that women need to work harder than men to achieve the same political goals. Even if this is a just perceived bias, held on by potential candidates and seasoned political agents alike, it certainly plays a role in defining what makes a women electible.

Yet, the negative correlation between positions of power and gender reveals that the double standard for women politicians is more than a mere 'perception'. We would expect, or 
hope, that more qualified politicians, regardless of their gender, would be more likely to be promoted to positions of power. This is assuming, as contemporary politics often does, that gender is irrelevant, or at the very least, a minor factor that should not define a politician's career. It appears that the negative bias Dolan found voters still hold against female candidates is not masked over by other voter priorities, such as party id. Since political parties hold their own biases against women's electability and continue to operate under a 'good old boys' networking system. The impact of these minor biases of women's perceived electability seems to be exaggerated, not masked, in single member districts.

Higher expectations for female candidate quality has very much lead to a reality of higher female MP quality. Women continue to be politically constrained by their gender alone. Women are expected by voters, political gatekeepers, and even by their friends, families and themselves, to gain voter appeal by outperforming the average male candidate. The reasoning is simple. Working harder, gaining more political experience, more expertise, and establishing more connections prior to election helps women overcome the informal discrimination that innately comes with being a female candidate. Women combat the damaging effects of their gender by focusing on aspects of their candidacy they do have control over, such as increasing their candidate quality.

Gender bias in the U.K.'s political system is even more drastically felt by female minority MPs. Minority women MPs feel a double standard which is two fold. Once for their minority status and then again for their gender. Minority MPs of both sexes clearly had different, and arguably more difficult, paths to Westminster compared to non-minority MPs. The observed exceedance in minority MP quality scores are testimony to more laborious and 
ambitious paths to national election. However, the fact that minority men can gain more influence due to their past experiences, while minority women cannot, is a testimony to just how deeply embedded sexism remains in contemporary democracies.

My data firmly reveals how patriarchy continues to prevail and hammers both women's equal representation and equal influence in politics. Women MPs consistently face more challenges to reach elected office than men yet they receive less because of it. The implications to this are astonishing. The gendered path to national election is disguised as the modern democratic candidate emergence process in the U.K. This gendered candidate emergence path very much undermines the democratic process of the U.K., and other SMD electoral systems. Furthermore, it threatens the democratic legitimacy of the state since half of the state's voting population's ability to run for election and gain influence is weakened. The implication of this gendered candidate emergence process alongside a gendered rewards system is that women lack the same opportunities to succeed compared to men. Recognition of this fact would mean recognition that women MPs are discriminated against on a large scale and that this discrimination is evidence of gender bias which systematically plays a major role in modern politics. Without women MPs gaining the proper weight of influence from their weight of quality, British politics will likely stay a man's world.

While gender bias appears to be fully rooted and cleverly masked within the U.K.'s political system, there does seem to be a slight hope for women. In the 2015 elections, $36 \%$ of the fifty-six seats filled by the Scottish National Party's were female, compared with $29 \%$ of the U.K.'s legislative body. Although, this is not equal representation, the Scottish National Party's Shadow Cabinet is equally represented by men and women. The intentional actions of party 
leader, Nicola Sturgeon, are an example of how political agents can deliberately loosen the grip patriarchy has on female representation and influence.

Nevertheless, the fact remains that women MPs often overcompensate for their non-political normative gender with higher levels of candidate quality due to a double standard of expectations and a history of exclusion from politics. Currently, the discussion around equal representation stays comfortably centered around the female politicians the U.K. has, instead of around the female politicians the U.K. could have. The reality of politically gendered discrimination keeps many women from pursuing national election. Most women qualified for political office are slipping through the cracks, choosing other career paths or perhaps staying in local government. As a result, while some women MPs manage to reach for the sky politically, most still hit the glass ceiling at Westminster. 


\section{Works Cited}

Brooks, Deborah Jordan. He Runs, She Runs: Why Gender Stereotypes Do Not Harm Women Candidates. Princeton: Princeton UP, 2013. Print.

Burrell, Barbara C. Gender in Campaigns for the U.S. House of Representatives. Ann Arbor: U of Michigan, 2014. Print.

Carroll, Susan J. The Impact of Women in Public Office. Bloomington: Indiana UP, 2001. Print. Carroll, Susan J., and Richard L. Fox. Gender and Elections: Shaping the Future of American Politics. 2nd ed. New York City: Cambridge UP, 2006. Print.

Dolan, Kathleen. When Does Gender Matter? Women Candidates and Gender Stereotypes in American Elections. New York City: Oxford UP, 2014. Print.

Dolan, Kathleen A. Voting for Women: How the Public Evaluates Women Candidates. Boulder: Westview, 2004. Print.

Farrell, David M. Electoral Systems. Vol. 1. New York City: Palgave Press, 2001. Print. Handlin, Amy. What Ever Happened to the Year of the Woman? Denver: Arden, 1998. Print. Kay, Katty, and Claire Shipman. "The Confidence Gap." The Atlantic: Business (2014). Print. Lawless, Jennifer L., and Richard Logan Fox. It Takes a Candidate: Why Women Don't Run for Office. Cambridge: Cambridge UP, 2005. Print.

Lawless, Jennifer L. Becoming a Candidate: Political Ambition and the Decision to Run for Office. Cambridge: Cambridge UP, 2012. Print.

Sanbonmatsu, Kira. Where Women Run: Gender and Party in the American States. Ann Arbor: University of Michigan, 2006. Print.

Norris, Pippa. Electoral Engineering: Voting Rules and Political Behavior. Cambridge: 
Cambridge UP, 2004. Print.

Ross, Karen. Women, Politics, and Change. Oxford: Oxford UP, 2002. Print.

Seltzer, Richard A., Jody Newman, and Melissa Voorhees Leighton. Sex as a Political Variable:

Women as Candidates and Voters in U.S. Elections. Boulder: Lynne Rienner, 1997. Print.

"SI-UK Education Council: London and Manchester." SI-UK Education Council: Top Ranking U.K. Universities. SI-UK. Web. 29 Feb. 2016.

Stokes, Wendy. Women in Contemporary Politics. Cambridge: Polity, 2005. Print.

Tremblay, Manon. Women and Legislative Representation: Electoral Systems, Political Parties, and Sex Quotas. New York City: Palgrave Macmillan, 2008. Print. 
. 


\section{Crosstabs}

gender * PhD * Minority Crosstabulation

count FIGURE 7

\begin{tabular}{|c|c|c|c|c|c|}
\hline \multirow{2}{*}{ Minorit } & & & \multicolumn{2}{|c|}{$\mathrm{PhD}$} & \multirow[b]{2}{*}{ Total } \\
\hline & & & \multirow{2}{*}{$\frac{\text { no }}{393}$} & \multirow{2}{*}{$\frac{\text { yes }}{23}$} & \\
\hline no & gender & male & & & 416 \\
\hline & & female & 152 & 12 & 164 \\
\hline & Total & & 545 & 35 & 580 \\
\hline \multirow[t]{3}{*}{ yes } & gender & male & 41 & 3 & 44 \\
\hline & & female & 25 & 1 & 26 \\
\hline & Total & & 66 & 4 & 70 \\
\hline \multirow[t]{3}{*}{ Total } & gender & male & 434 & 26 & 460 \\
\hline & & female & 177 & 13 & 190 \\
\hline & Total & & 611 & 39 & 650 \\
\hline
\end{tabular}

gender * LawDegree * Minority Crosstabulation

Count FIGURE 2

\begin{tabular}{|c|c|c|c|c|c|}
\hline \multirow{2}{*}{ Minorit } & & & \multicolumn{2}{|c|}{ LawDegree } & \multirow[b]{2}{*}{ Total } \\
\hline & & & no & yes & \\
\hline & gender & male & 356 & 60 & 416 \\
\hline & & female & 137 & 27 & 164 \\
\hline & Total & & 493 & 87 & 580 \\
\hline \multirow[t]{3}{*}{ yes } & gender & male & 31 & 13 & 44 \\
\hline & & female & 16 & 10 & 26 \\
\hline & Total & & 47 & 23 & 70 \\
\hline \multirow[t]{3}{*}{ Total } & gender & male & 387 & 73 & 460 \\
\hline & & female & 153 & 37 & 190 \\
\hline & Total & & 540 & 110 & 650 \\
\hline
\end{tabular}


gender * MA * Minority Crosstabulation

Count FIGURE 3

\begin{tabular}{|c|c|c|c|c|c|}
\hline \multirow{2}{*}{\multicolumn{3}{|c|}{ Minority }} & \multicolumn{2}{|c|}{ MA } & \multirow[b]{2}{*}{ Total } \\
\hline & & & \multirow{3}{*}{$\begin{array}{c}\text { no } \\
342 \\
127 \\
\end{array}$} & \multirow{3}{*}{$\begin{array}{r}\text { yes } \\
7.4 \\
37\end{array}$} & \\
\hline no & gender & male & & & 416 \\
\hline & & female & & & 164 \\
\hline & Total & & 469 & 111 & 580 \\
\hline \multirow[t]{3}{*}{ yes } & gender & male & 30 & 14 & 44 \\
\hline & & female & 17 & 9 & 26 \\
\hline & Total & & 47 & 23 & 70 \\
\hline \multirow[t]{3}{*}{ Total } & gender & male & 372 & 88 & 460 \\
\hline & . & female & 144 & 46 & 190 \\
\hline & Total & . & 516 & 134 & 650 \\
\hline
\end{tabular}

gender * PrestigiousUni * Minority Crosstabulation

Count FIGURE 4

\begin{tabular}{|c|c|c|c|c|c|}
\hline \multirow{2}{*}{\multicolumn{3}{|c|}{ Minority }} & \multicolumn{2}{|c|}{ PrestigiousUní } & \multirow[b]{2}{*}{ Total } \\
\hline & & & no & yes & \\
\hline \multirow[t]{3}{*}{ no } & gender & male & 239 & 177 & 416 \\
\hline & & female & 92 & 72 & 164 \\
\hline & Total & & 331 & 249 & 580 \\
\hline \multirow[t]{3}{*}{ yes } & gender & male & 17 & 27 & 44 \\
\hline & & female & 5 & 21 & 26 \\
\hline & Total & & 22 & 48 & 70 \\
\hline \multirow[t]{3}{*}{ Total } & gender & male & 256 & 204 & 460 \\
\hline & & female & 97 & 93 & 190 \\
\hline & Total & & 353 & 297 & 650 \\
\hline
\end{tabular}

gender * LocalCouncilBoardGov * Mînority Crosstabulation

Count FIGURE 5

\begin{tabular}{|c|c|c|c|c|c|c|}
\hline \multirow{2}{*}{\multicolumn{3}{|c|}{ Minority }} & \multicolumn{2}{|c|}{ LocalCouncilBoardGov } & \multirow[b]{2}{*}{ Total } & \multirow{4}{*}{$\begin{array}{l}52 \% \\
65 \%\end{array}$} \\
\hline & & & no & yes & & \\
\hline \multirow[t]{3}{*}{ no } & gender & male & 197 & 219 & 416 & \\
\hline & & female & 57 & 107 & 164 & \\
\hline & Total & & 254 & 326 & 580 & \multirow{7}{*}{$\begin{array}{l}57 \% \\
50 \% \\
53 \% \\
63 \%\end{array}$} \\
\hline \multirow[t]{3}{*}{ yes } & gender & male & 19 & 25 & 44 & \\
\hline & & female & 13 & 13 & 26 & \\
\hline & Total & & 32 & 38 & 70 & \\
\hline \multirow[t]{3}{*}{ Total } & gender & male & 216 & 244 & 460 & \\
\hline & & female & 70 & 120 & 190 & \\
\hline & Total & & 286 & 364 & 650 & \\
\hline
\end{tabular}


gender * LocalPartyLeadership * Minority Crosstabulation

\begin{tabular}{|c|c|c|c|c|c|c|}
\hline \multirow{3}{*}{ Minorit } & & & \multirow{2}{*}{\multicolumn{2}{|c|}{ LocalPartyLeadership }} & \multirow{3}{*}{ Total } & \multirow{6}{*}{$\begin{array}{l}45 \% \\
50 \%\end{array}$} \\
\hline & & & & & & \\
\hline & & & no & yes & & \\
\hline \multirow[t]{3}{*}{ no } & gender & male & 229 & 187 & 416 & \\
\hline & & female & 82 & 82 & 164 & \\
\hline & Total & & 311 & 269 & 580 & \\
\hline \multirow[t]{3}{*}{ yes } & gender & male & 27 & 17 & 44 & \multirow{6}{*}{$\begin{array}{l}39 \% \\
50 \% \\
44 \% \\
50 \%\end{array}$} \\
\hline & & female & 13 & 13 & 26 & \\
\hline & Total & & 40 & 30 & 70 & \\
\hline \multirow[t]{3}{*}{ Total } & gender & male & 256 & 204 & 460 & \\
\hline & & female & 95 & 95 & 190 & \\
\hline & Total & & 351 & 299 & 650 & \\
\hline
\end{tabular}

gender * LawJusticepratice * Minority Crosstabulation

count FIGURE 7

\begin{tabular}{|c|c|c|c|c|c|c|}
\hline \multirow{2}{*}{ Minorit } & & & \multicolumn{2}{|c|}{ LawJusticepratice } & \multirow[b]{2}{*}{ Total } & \multirow{4}{*}{$\begin{array}{l}12 \% \\
12 \%\end{array}$} \\
\hline & & & no & yes & & \\
\hline \multirow[t]{3}{*}{ no } & gender & male & 366 & 50 & 416 & \\
\hline & & female & 145 & 19 & 164 & \\
\hline & Total & & 511 & 69 & 580 & \multirow{7}{*}{$\begin{array}{l}35 \% \\
13 \% \\
15 \%\end{array}$} \\
\hline \multirow[t]{3}{*}{ yes } & gender & male & 34 & 10 & 44 & \\
\hline & & female & 17 & 9 & 26 & \\
\hline & Total & & 51 & 19 & 70 & \\
\hline \multirow[t]{3}{*}{ Total } & gender & male & 400 & 60 & 460 & \\
\hline & & female & 162 & 28 & 190 & \\
\hline & Total & & 562 & 88 & 650 & \\
\hline
\end{tabular}

gender * workedforMP * Minority Crosstabulation

Count FIGURE 8

\begin{tabular}{|c|c|c|c|c|c|}
\hline \multirow{2}{*}{\multicolumn{3}{|c|}{ Minority }} & \multicolumn{2}{|c|}{ workedforMP } & \multirow{3}{*}{$\frac{\text { Total }}{416}$} \\
\hline & & & no & yes & \\
\hline \multirow[t]{3}{*}{ no } & \multirow[t]{2}{*}{ gender } & male & 329 & 87 & \\
\hline & & female & 124 & 40 & 164 \\
\hline & Total & & 453 & 127 & 580 \\
\hline \multirow[t]{3}{*}{ yes } & gender & male & 33 & 11 & 44 \\
\hline & & female & 16 & 10 & 26 \\
\hline & Total & & 49 & 21 & 70 \\
\hline \multirow[t]{3}{*}{ Total } & gender & male & 362 & 98 & 460 \\
\hline & & female & 140 & 50 & 190 \\
\hline & Total & & 502 & 148 & 650 \\
\hline
\end{tabular}


gender * ActivistAward * Minority Crosstabulation

count FIGURE 9

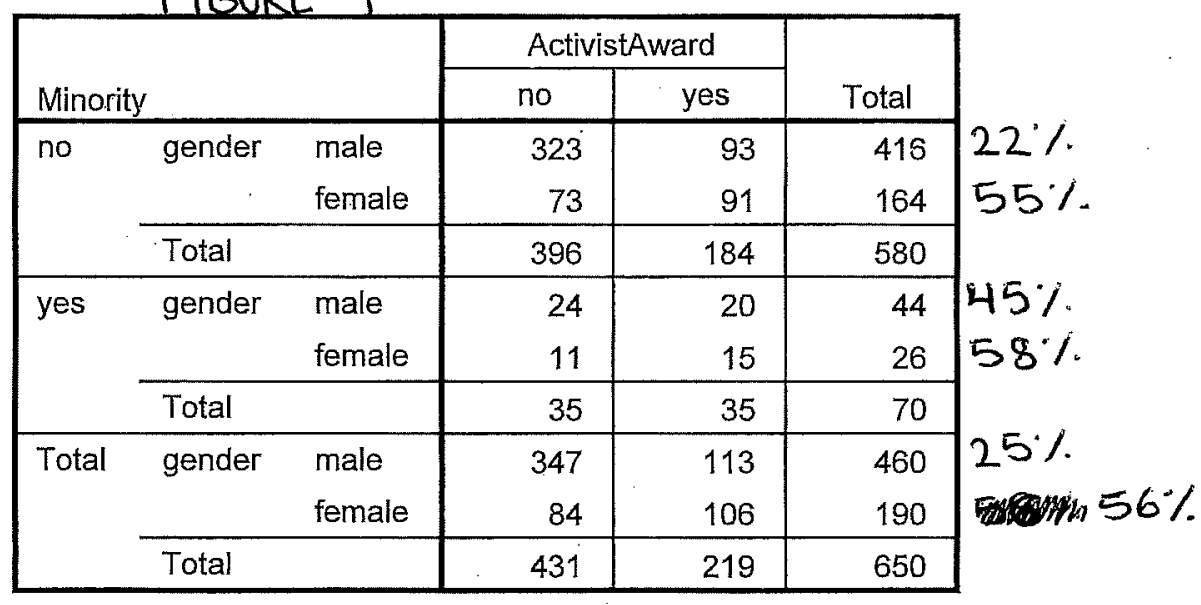

gender * ParyLeaderEver * Minority Crosstabulation

Count FIGURE 10

\begin{tabular}{|c|c|c|c|c|c|}
\hline \multirow{2}{*}{\multicolumn{3}{|c|}{ Minority }} & \multicolumn{2}{|c|}{ ParyLeaderEver } & \multirow{2}{*}{ Total } \\
\hline & & & no & yes & \\
\hline \multirow[t]{3}{*}{ no } & \multirow[t]{2}{*}{ gender } & male & 406 & 10 & \multirow{2}{*}{$\begin{array}{l}416 \\
164 \\
\end{array}$} \\
\hline & & female & 161 & 3 & \\
\hline & \multicolumn{2}{|l|}{ Total } & 567 & 13 & 580 \\
\hline \multirow[t]{3}{*}{ yes } & \multirow[t]{2}{*}{ gender } & male & 44 & & 44 \\
\hline & & female & 26 & & 26 \\
\hline & \multicolumn{2}{|l|}{ Total } & 70 & & 70 \\
\hline \multirow[t]{3}{*}{ Total } & \multirow[t]{2}{*}{ gender } & male & 450 & 10 & 460 \\
\hline & & female & 187 & 3 & 190 \\
\hline & \multicolumn{2}{|l|}{ Total } & 637 & 13 & 650 \\
\hline
\end{tabular}

gender * CabinetLeader * Minority Crosstabulation

count FIGURE U

\begin{tabular}{|c|c|c|c|c|c|}
\hline \multirow{2}{*}{\multicolumn{3}{|c|}{ Minority }} & \multicolumn{2}{|c|}{ CabinetLeader } & \multirow{3}{*}{$\frac{\text { Total }}{416}$} \\
\hline & & & no & yes & \\
\hline \multirow[t]{3}{*}{ no } & gender & male & 336 & 80 & \\
\hline & & female & 138 & 26 & 164 \\
\hline & Total & & 474 & 106 & 580 \\
\hline \multirow[t]{3}{*}{ yes } & gender & male & 30 & 14 & 44 \\
\hline & & female & 22 & 4 & 26 \\
\hline & Total & & 52 & 18 & 70 \\
\hline \multirow[t]{3}{*}{ Total } & gender & male & 366 & 94 & 460 \\
\hline & & female & 160 & 30 & 190 \\
\hline & Total & & 526 & 124 & 650 \\
\hline
\end{tabular}


gender * Whip * Minority Crosstabulation

Count FIGURE 12

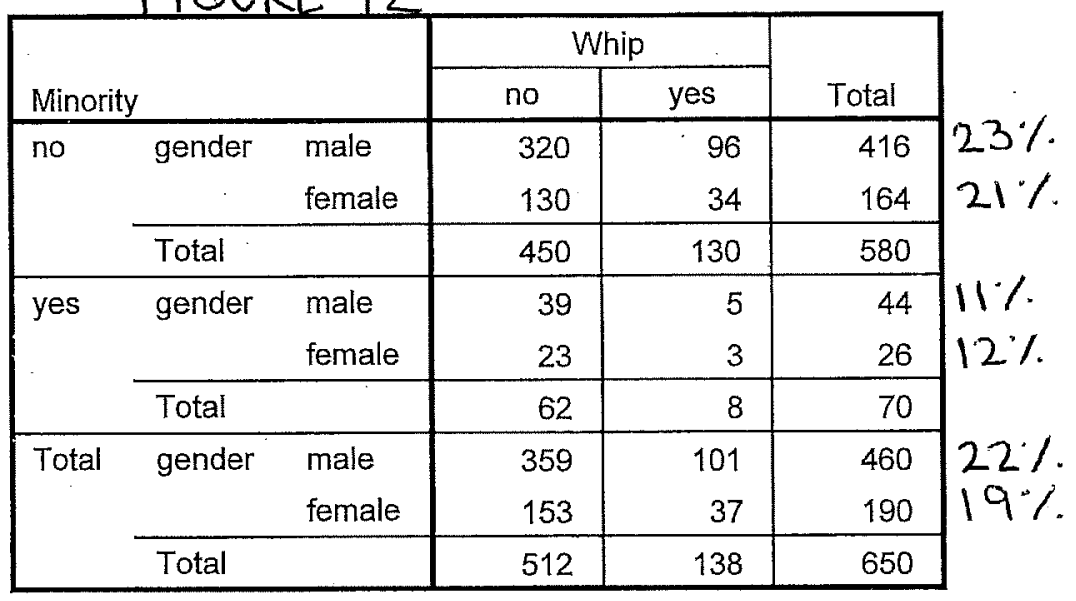

gender * ShadowCabenitLead * Minority Crosstabulation

Count FIGURE 13

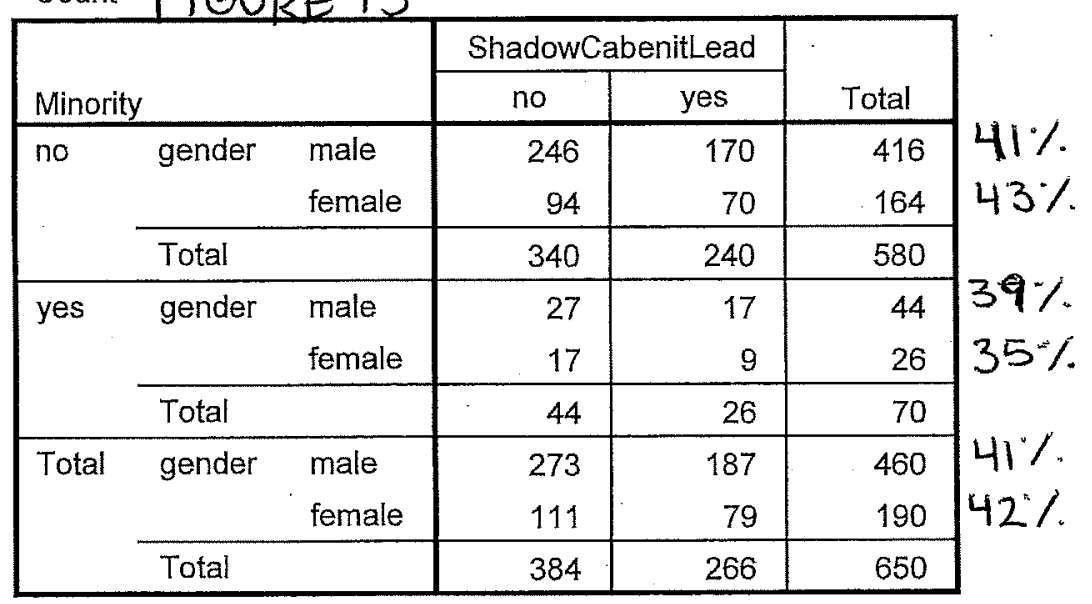

gender * RightHonorable * Minority Crosstabulation

Count FIGURE 14

\begin{tabular}{|c|c|c|c|c|c|}
\hline \multirow{2}{*}{\multicolumn{3}{|c|}{ Minority }} & \multicolumn{2}{|c|}{ RightHonorable } & \multirow{3}{*}{$\frac{\text { Total }}{416}$} \\
\hline & & & no & yes & \\
\hline \multirow[t]{3}{*}{ no } & gender & male & 354 & 62 & \\
\hline & & female & 147 & 17 & 164 \\
\hline & Total & & 501 & 79 & 580 \\
\hline \multirow[t]{3}{*}{ yes } & gender & male & 36 & 8 & 44 \\
\hline & & female & 24 & 2 & 26 \\
\hline & Total & & 60 & 10 & 70 \\
\hline \multirow[t]{3}{*}{ Total } & gender & male & 390 & 70 & 460 \\
\hline & & female & 171 & 19 & 190 \\
\hline & Total & & 561 & 89 & 650 \\
\hline
\end{tabular}





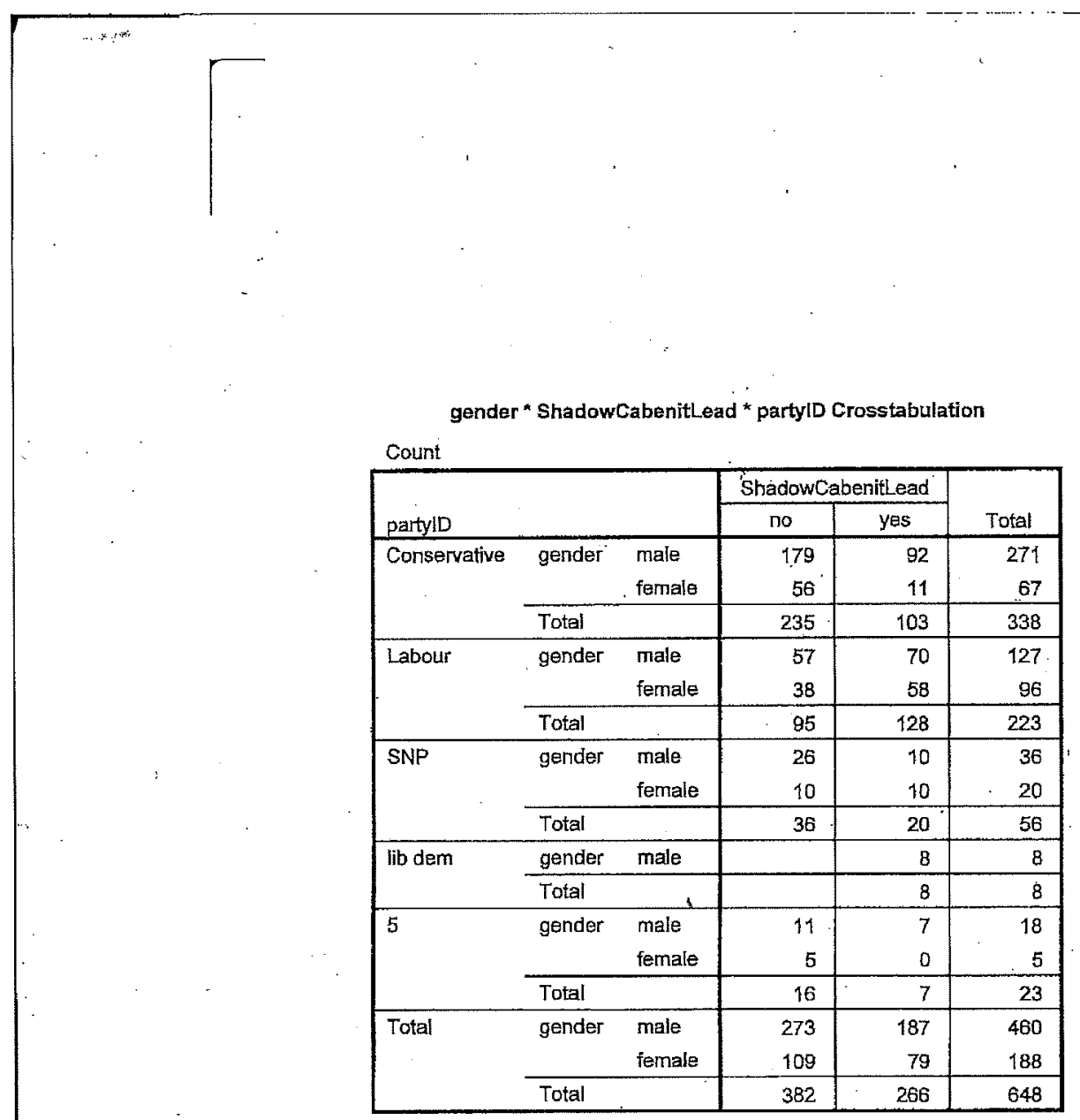


